\title{
Removal of tetracycline from wastewater using pumice stone: equilibrium, kinetic and thermodynamic studies
}

\author{
Ulker Asli Guler ${ }^{*}$ and Meltem Sarioglu
}

\begin{abstract}
In this study, pumice stone was used for the removal of tetracyline (TC) from aqueous solutions. It was characterized by XRD, FT-IR, SEM and BET analyses. Cation exchange capacity of pumice stone was found to be $9.9 \mathrm{meq} / 100 \mathrm{~g}$. Effect of various parameters such as solution pH (2-11), adsorbent dosage $(0.5-10 \mathrm{~g} / \mathrm{L})$, contact time (2.5-120 min), initial TC concentration $(5-300 \mathrm{mg} / \mathrm{L})$ and temperature $\left(20-50^{\circ} \mathrm{C}\right)$ on TC adsorption onto pumice was investigated. Also the adsorption of TC on pumice stone was studied as a function of $\mathrm{Na}^{+}$and $\mathrm{Cu}^{2+}$ cations changing $\mathrm{pH}$ from 2 to 11 using batch experiments. The best removal efficiency performance was exhibited at adsorbent dosage $10 \mathrm{~g} / \mathrm{L}, \mathrm{pH}$ 3, contact time 120 min. Langmuir, Freundlich and Dubinin-Radushkevich (D-R) isotherm models were applied to the equilibrium data. The result has shown that the adsorption was favorable, physicochemical in nature and agrees well with Langmuir and Freundlich models. The maximum Langmuir adsorption capacity was found to be $20.02 \mathrm{mg} / \mathrm{g}$. The adsorption behavior of TC on pumices stone was fitted well in the pseudo-second order kinetics model. Thermodynamic parameters calculated from the adsorption data at different temperature showed that the adsorption reaction was feasible, spontaneous and exothermic.
\end{abstract}

Keywords: Tetracyline, Antibiotic, Adsorption, Pumice stone, $\mathrm{Na}^{+}, \mathrm{Cu}^{2+}$

\section{Introduction}

Antibiotics are used the worldwide in human and veterinary medicine for about 70 years [1-3]. TCs are the second most common antibiotic family in both production and usage in the world [4]. TCs are relatively poorly absorbed by humans and animals. Large fractions of antibiotics including TC are excreted through urine and feces as unmodified main compound [3,5-9].

Residues of TC are frequently detected in soil and various environmental water samples such as surface water, ground water and drinking water [1,3,5,10-12]. The presence of residual antibiotics in soil and water is potentially hazardous for the bacteria and non-target organisms and these can promote the selection of genetic variants of microorganisms resulting in the occurrence of antibiotic resistant pathogens [13-17].

The chemical structure of TC and the speciation diagram of $\mathrm{TC}$ as a function of $\mathrm{pH}$ are given in Figure 1a and

\footnotetext{
* Correspondence: ulkerasli@gmail.com

Department of Environmental Engineering, Engineering Faculty, Cumhuriyet University, Sivas 58140, Turkey
}

Figure $1 \mathrm{~b}$, respectively. The pKa values of $\mathrm{TC}$ are $3.3,7.7$ and $9.7[18,19]$.

TC molecule is strongly polar and has three protonactive groups: a dimethylamine $(\mathrm{C}-4)$, a tricarbonylamide group (C-1:C-2:C-3) and a phenolic diketone groups (C-10:C-11:C-12) (Figure 1) [3,9,20,21].

Many adsorbent has been used for TC removal from wastewaters; in this study the pumice stone was used for TC removal from wastewaters with comprehensive research.

TCs are highly adsorbed by several materials such as clay, montmorillonite, rectorite, palygorskite, chitosan particles, oxide minerals, humic substances, soil, activated carbon and sediments [3,7,15,17,20,22-29].

Pumice is a light, porous and volcanic stone with a large surface area. It is generally pale in color, ranging from white, cream, blue or grey, to green-brown or black [30] and used as an adsorbent, filter bed and support material in water and wastewater treatment [31-33].

In this study, effects of solution $\mathrm{pH}$, adsorbent dosage, temperature, $\mathrm{Na}^{+}$and $\mathrm{Cu}^{2+}$ cations on the TC adsorption 


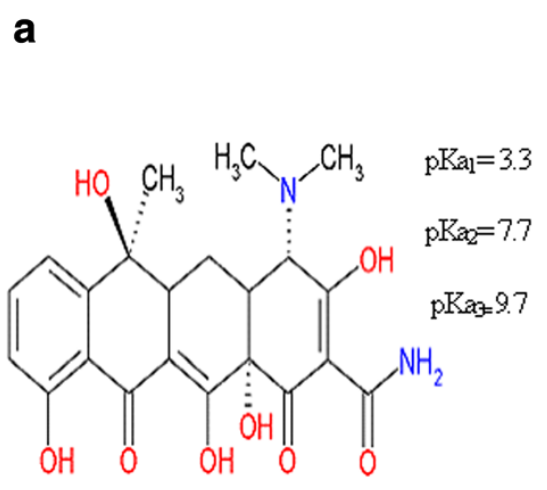

b

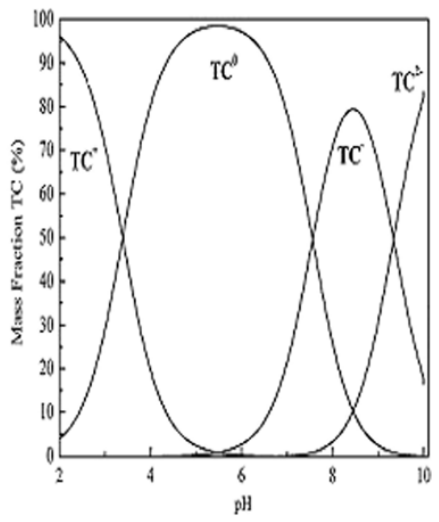

Figure 1 Chemical structure (a) and the speciation diagram (b) of TC as a function of $\mathrm{pH}$.

Table 1 Properties of pumice stone

\begin{tabular}{lllllll}
\hline Adsorbent & Details & $\begin{array}{l}\text { Specific surface } \\
\text { area }\left(\mathbf{m}^{\mathbf{2}} \mathbf{g}^{-\mathbf{1}}\right)\end{array}$ & $\begin{array}{l}\text { Total pore } \\
\text { volume }\left(\mathbf{c m}^{\mathbf{3}} \mathbf{g}^{-\mathbf{1}}\right)\end{array}$ & $\begin{array}{l}\text { Mean pore } \\
\text { diameter }(\mathbf{n m})\end{array}$ & $\begin{array}{c}\mathrm{pH} \\
\mathrm{pzc}\end{array}$ & $\mathrm{CEC}(\mathbf{m e q} / \mathbf{1 0 0} \mathbf{g})$ \\
\hline Pumice stone & Light grey/brown granular & 11.88 & 0.0410 & 13.813 & 8.34 & 9.9 \\
\hline
\end{tabular}

by pumice stone were investigated. The adsorption isotherms, kinetics and thermodynamics were studied by batch experiments. In addition, the experimental results were combined with XRD, FT-IR and SEM analyses in order to identify in the interaction between pumice stone and TC and the specific surface area and components of pumice stone were determined by BET and XRF analyses, respectively.

\section{Materials and methods}

\section{Adsorbent}

Pumice stone was supplied from Kayseri-Basakpinar in Turkey. It was washed with distilled water several times and dried at $50^{\circ} \mathrm{C}$ in oven. Later, particle size of dried pumice stone was grinded to $0.125 \mathrm{~mm}$ below. The physicochemical properties and XRF analysis of pumice stone are listed in Table 1 and Table 2, respectively. Cation Exchange Capacity (CEC) was determined through ion exchange of sodium and potassium ions in the effluent.

\section{Batch experiments}

The batch experiments were carried out in $250 \mathrm{~mL}$ Erlenmeyer containing $100 \mathrm{~mL}$ of aqueous solution. $\mathrm{pH}$ was adjusted with $\mathrm{HCl}$ and $\mathrm{NaOH}$. The suspension was shaken in temperature controlled shaker at $130 \mathrm{rpm}$. The residual concentration of TC in supernatant was analysed by CHEBIOUS UV-spectrophotometer at $\lambda_{\max }$ value of TC (357 nm wavelength). Effects of solution $\mathrm{pH}$ (2.0-11), adsorbent dosage $(0.5-10 \mathrm{~g} / \mathrm{L})$, contact time (2.5-120 min), initial TC concentration $(5-300 \mathrm{mg} / \mathrm{L})$ and temperature $\left(20-50^{\circ} \mathrm{C}\right)$ on adsorption of $\mathrm{TC}$ by pumice stone were investigated. In addition, the effects of $\mathrm{Na}^{+}$and $\mathrm{Cu}^{2+}$ cations on the TC adsorption were investigated as a function of $\mathrm{pH}$. The details of the experimental conditions are presented in Table 3.

The adsorption capacity $\left(\mathrm{q}_{\mathrm{e}}, \mathrm{mg} / \mathrm{g}\right)$ and removal efficiency (\%) were determined with following equations:

$$
\begin{aligned}
& q_{e}=\frac{\left(C_{o}-C_{e}\right) V}{m} \\
& \text { Removalefficiency }(\%)=\frac{C_{o}-C_{e}}{C_{o}} \times 100
\end{aligned}
$$

where $C_{o}$ and $C_{\mathrm{e}}$ are the initial and the equilibrium TC concentration $(\mathrm{mg} / \mathrm{L}), V$ is the volume of solution (L) and $m$ is the amount of pumice stone (g).

\section{Table 2 XRF analysis of pumice stone}

\begin{tabular}{llll}
\hline Compound & \% by weight & Compound & \% by weight \\
\hline $\mathrm{SiO}_{2}$ & 69.27 & $\mathrm{P}_{2} \mathrm{O}_{5}$ & 0.08 \\
$\mathrm{Al}_{2} \mathrm{O}_{3}$ & 14.24 & $\mathrm{MnO}$ & 0.07 \\
$\mathrm{~K}_{2} \mathrm{O}$ & 3.89 & $\mathrm{BaO}$ & 0.06 \\
$\mathrm{Na}_{2} \mathrm{O}$ & 3.61 & $\mathrm{ZrO}_{2}$ & 0.05 \\
$\mathrm{Fe}_{2} \mathrm{O}_{3}$ & 2.90 & $\mathrm{Cr}_{2} \mathrm{O}_{3}$ & 0.01 \\
$\mathrm{CaO}$ & 1.82 & $\mathrm{ZnO}$ & 0.01 \\
$\mathrm{MgO}$ & 0.49 & Loss on ignition & 2.95 \\
$\mathrm{TiO}_{2}$ & 0.45 & Total & $\mathbf{1 0 0 . 0 0}$ \\
$\mathrm{SO}_{3}$ & 0.10 & & \\
\hline
\end{tabular}


Table 3 Experimental conditions

\begin{tabular}{|c|c|c|c|c|c|c|}
\hline \multicolumn{7}{|c|}{ Experimental conditions } \\
\hline Set & Aim of experiment & Solution $\mathrm{pH}$ & TC conc. (mg/L) & Adsorbent dosage $(\mathrm{g} / \mathrm{L})$ & Contact time (min) & Temperature \\
\hline 1 & Effect of solution $\mathrm{pH}$ & $2.0-11.0$ & 50 & 10 & 120 & Room temperature $\left(20^{\circ} \mathrm{C}\right)$ \\
\hline 2 & Effect of adsorbent dosage & 3.0 & 50 & $0.5-10$ & 120 & Room temperature $\left(20^{\circ} \mathrm{C}\right)$ \\
\hline 3 & Adsorption kinetics & 3.0 & 50 & 10 & $2.5-120$ & Room temperature $\left(20^{\circ} \mathrm{C}\right)$ \\
\hline 4 & Adsorption equilibrium tests & 3.0 & $5-300$ & 10 & 120 & Room temperature $\left(20^{\circ} \mathrm{C}\right)$ \\
\hline 5 & Effect of temperature & 3.0 & 50 & 10 & 120 & $20-50^{\circ} \mathrm{C}$ \\
\hline 6 & $\begin{array}{l}\text { Effects of } 0.01 \mathrm{M} \mathrm{Na}^{+} \text {and } \\
0.1 \mathrm{mM} \mathrm{Cu}^{2+}\end{array}$ & $2.0-11.0$ & 50 & 10 & 120 & Room temperature $\left(20^{\circ} \mathrm{C}\right)$ \\
\hline
\end{tabular}

\section{Results and discussion}

\section{Adsorbent characterization}

XRD, FT-IR and SEM analyses of pumice stone before and after (TC-P) the adsorption of TC are shown in Figures 2, 3 and 4 , respectively.
According to the result of XRD pattern of the pumice stone, there were three peaks at 22, 28 and $59^{\circ}$ (Figure 2). These peaks related to the mineral dachiardite $(\mathrm{Ca}, \mathrm{Na}$, $\mathrm{K}, \mathrm{Al}, \mathrm{Si}, \mathrm{H}_{2} \mathrm{O}$ ). The 100 peak of the quartz is known to be at $2 \theta=26.65^{\circ}$. This finding points out amorphous
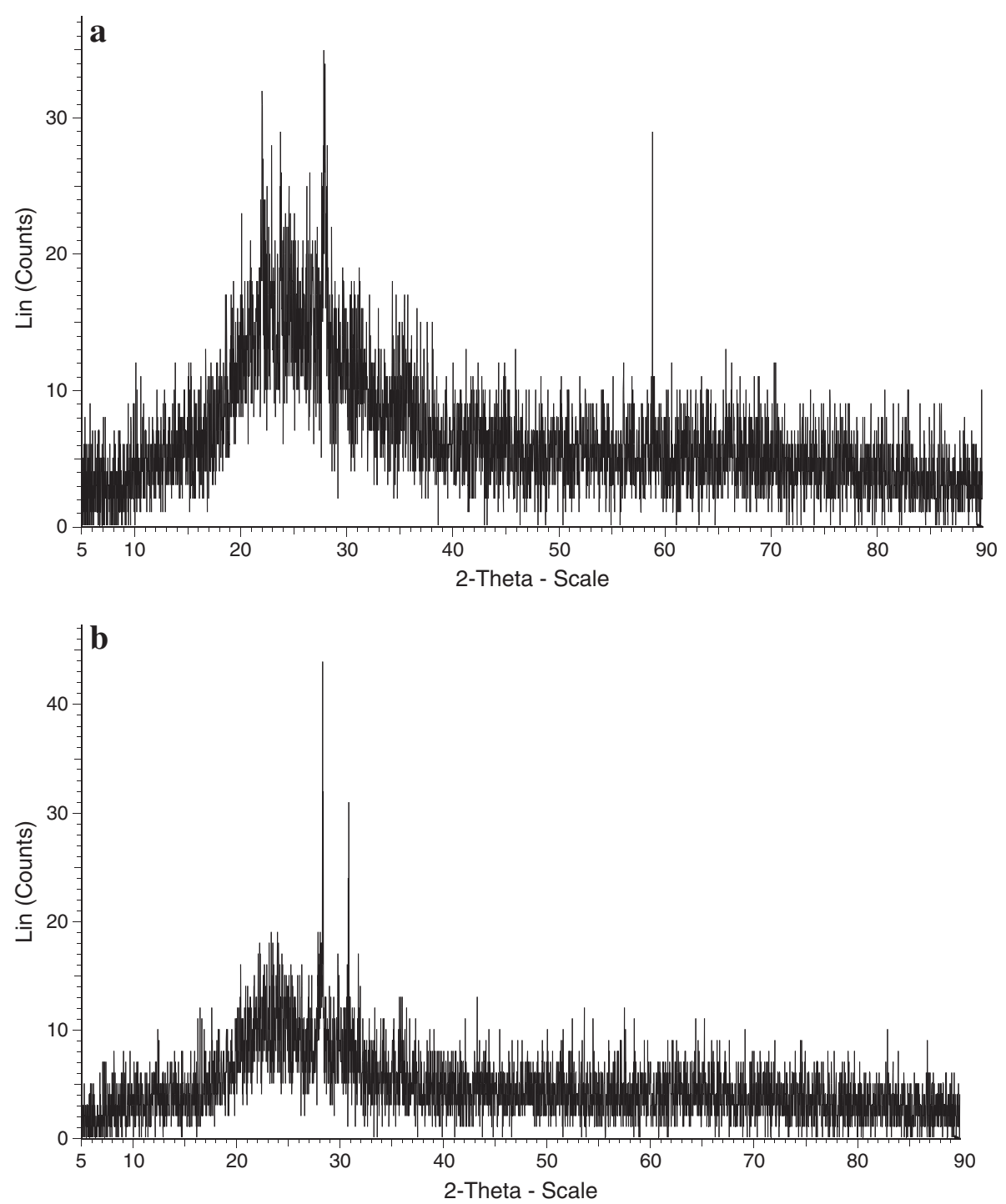

Figure 2 XRD patterns of pumice stone (a) and TC-P (b). 


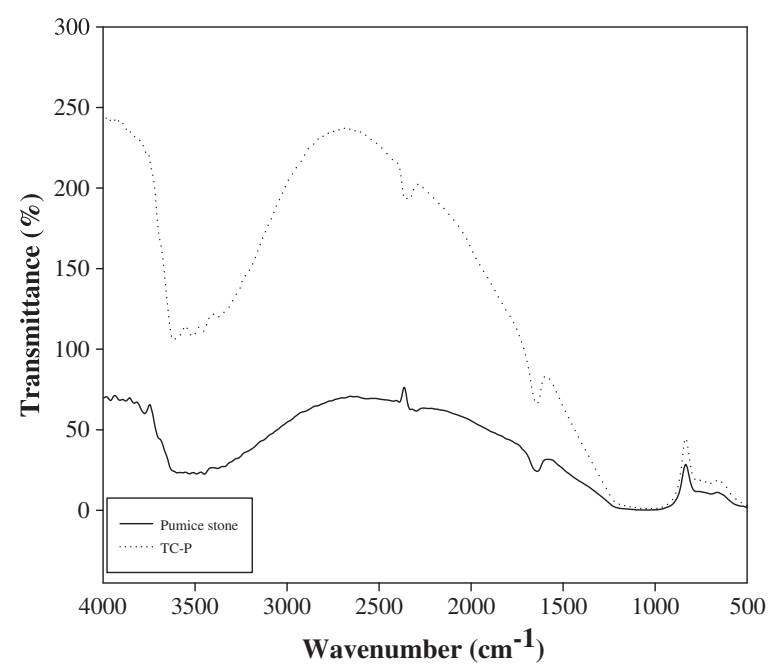

Figure 3 FT-IR spectra of pumice stone and TC-P.

quartz substance [34]. Similar results were also observed with the studies of other researchers [34-36]. The peaks of TC-P were observed at 28 and $31^{\circ}$. The changes of peaks are evidence of TC adsorption. As can be seen from XRF results, the two most important components of the pumice stone were $\mathrm{SiO}_{2}(69.27 \%)$ and $\mathrm{Al}_{2} \mathrm{O}_{3}$ (14.24\%) (see Table 1). It can be concluded that the higher the silica percentage, the purer the pumice stone will be [34].

The most characteristic peaks of pumice stone and TC-P are 800, 1700 and $3500 \mathrm{~cm}^{-1}$. The peak at $800 \mathrm{~cm}^{-1}$ in FT-IR spectra of the pumice stone (Figure 3) may have resulted from the $\mathrm{Si}-\mathrm{O}$ bending strength vibrations of the amorphous quartz. The peak at $1700 \mathrm{~cm}^{-1} \mathrm{can}$ be assigned to amide $\mathrm{I}$ or $\mathrm{C}=\mathrm{O}$ amide stretching and the amide group played an important role in TC adsorption. The other peak was observed around $3500 \mathrm{~cm}^{-1}$. This peak indicates the $\mathrm{OH}$ stretching vibrations of the adsorbed water (moisture) by the pumice stone from the outside environment [34,37]. These peaks were also determined with prior studies $[34,37,38]$.

As can seen be from FT-IR spectra of TC-P, the peak at $1700 \mathrm{~cm}^{-1}$ of TC-P were observed different from the natural pumice stone. The band changes of amide $\mathrm{I}$ or $\mathrm{C}=\mathrm{O}$ amide groups at $1700 \mathrm{~cm}^{-1}$ demonstrated that $\mathrm{TC}$ was adsorbed to the pumice stone with cation exchange and surface complexation [39].

The SEM images of natural pumice stone and TC-P indicated that the surface of pumice stone had a large porous surface and external surface of pumice stone was covered by $\mathrm{TC}$, respectively (Figure 4 ). In addition, the specific surface area, total pore volume and mean pore diameter of pumice stone were $11.88 \mathrm{~m}^{2} \mathrm{~g}^{-1}, 0.0410$ $\mathrm{cm}^{3} \mathrm{~g}^{-1}$ and $13.813 \mathrm{~nm}$, respectively.
Effects of solution $\mathrm{pH}$ and $\mathrm{Na}^{+}$and $\mathrm{Cu}^{2+}$ cations on adsorption The effects of solution $\mathrm{pH}$ and $\mathrm{Na}^{+}$and metal cation $\left(\mathrm{Cu}^{2+}\right)$ on the TC adsorption onto pumice stone were investigated and results are shown in Figure 5. It can be seen that the adsorption of TC onto pumice stone was highly affected with the solution $\mathrm{pH}$. When the solution $\mathrm{pH}$ was less than $\mathrm{pKa}_{2}$ (7.7) of TC, adsorption capacity of pumice stone varied from $3.80 \mathrm{mg} / \mathrm{g}$ to $2.30 \mathrm{mg} / \mathrm{g}$ at initial concentrations of $50 \mathrm{mg} / \mathrm{L}$ (Figure 5). Above $\mathrm{pKa}_{2}$, TC adsorption capacity of pumice stone decreased sharply to $0.59 \mathrm{mg} / \mathrm{g}$ at $\mathrm{pH} 10$. This $\mathrm{pH} 10$ and above there was almost no removal of TC from solution any more. Similar results were reported for TC adsorption onto graphene oxide and humic acid by other researches $[3,9]$.

The zero point of charge $\left(\mathrm{pH}_{\mathrm{pzc}}\right)$ of pumice stone was found to be 8.34 (Figure 5). According to PZC value, pumice stone was positively charged at $\mathrm{pH}<8.34$ and negatively charged at $\mathrm{pH}>8.34$. The $\mathrm{pKa}$ values of TC molecule were $3.3,7.7$ and 9.27, respectively $[1,40]$. TC existed as cationic in strong acid solution at $\mathrm{pH}<3.3$, zwitter anions at $3.3<\mathrm{pH}<7.7$ and negative ions at $\mathrm{pH}>$ $7.7[1,40,41]$. In this case, adsorption mechanisms depending on $\mathrm{pH}$ were given in Table 4 .

Positively charge pumice stone $<\mathrm{pH}_{\mathrm{pzc}}<$ negatively charge pumice stone.
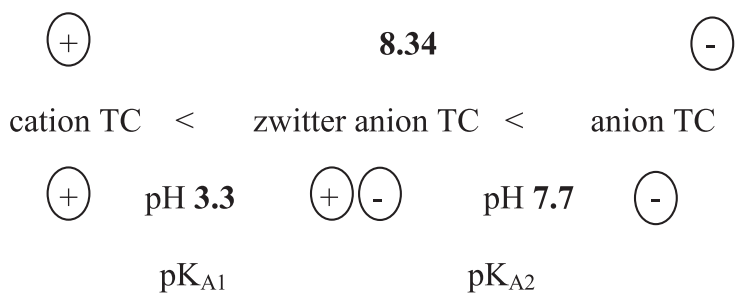

The cation exchange mechanism between cations of $\mathrm{TC}$ and positively charged pumice stone surface was dominated at low $\mathrm{pH}$ values. A surface complexation mechanism for zwitter anion of TC was important, which was accompanied with proton uptake on pumice stone $[19,23,42]$. Physical mechanisms such as van der Waals forces attraction and hydrogen bonding between polar TC groups and acidic groups on the surface of pumice stone may also contribute to surface complexation mechanism in TC adsorption [22,23]. The decrease in TC removal under alkaline conditions may be due to competition of excess hydroxyl ions with anion $\mathrm{TC}$ for active sites on pumice stone [30]. The $\mathrm{pH}_{\mathrm{PZC}}$ values of pumice stone in literature ranged between 6.9 and 9.3 [32]. The PZC value found in study is compatible with literature.

In order to determine the effects of $\mathrm{Na}^{+}$and $\mathrm{Cu}^{2+}$ ions on the TC adsorption, $0.1 \mathrm{mM} \mathrm{Cu}{ }^{2+}$ and $0.01 \mathrm{M} \mathrm{Na}^{+}$ cations were simultaneously adsorbed with TC at initial concentration of $50 \mathrm{mg} / \mathrm{L}$. The results of $\mathrm{TC}$ adsorption 

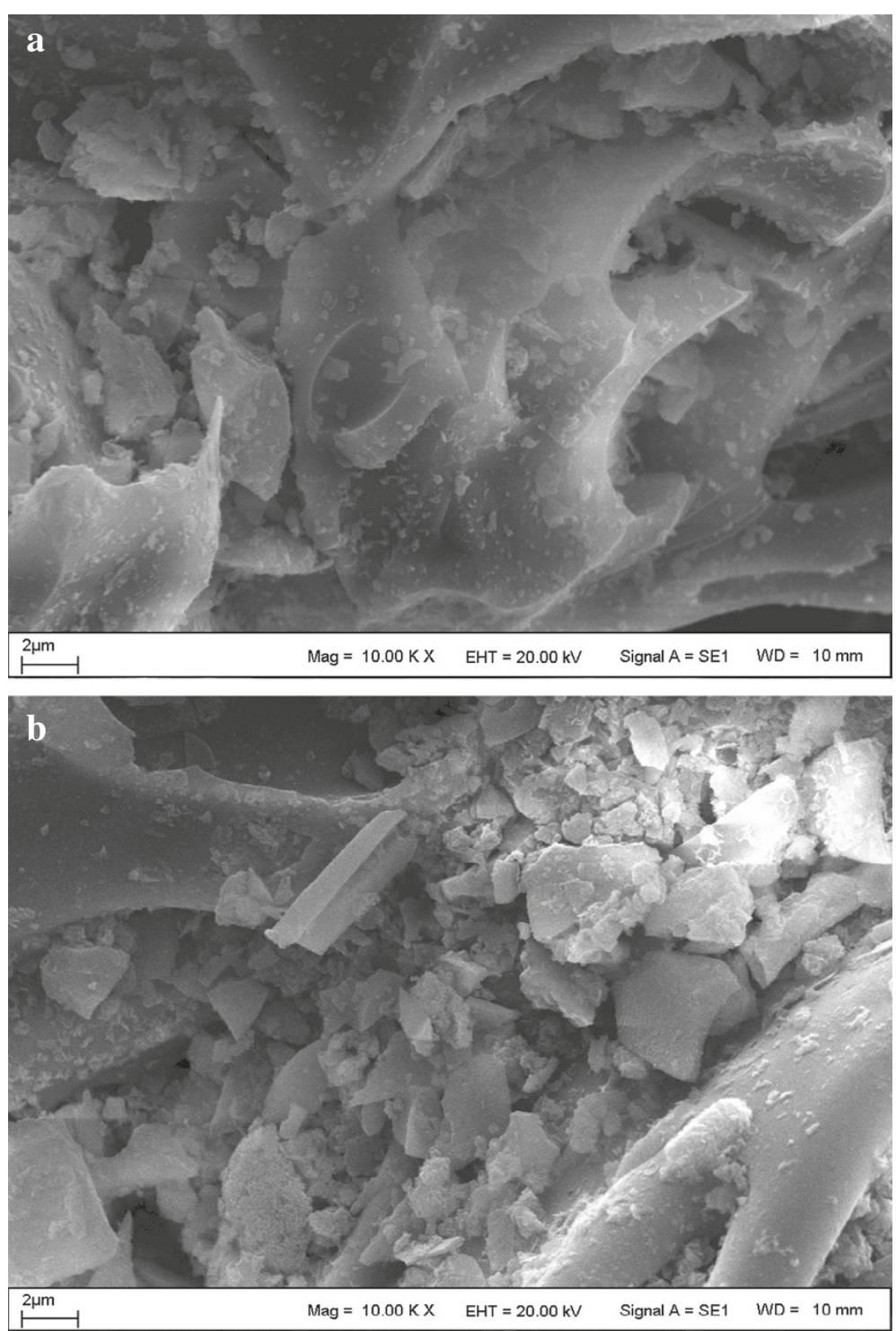

Figure 4 SEM images of pumice stone (a) and TC-P (b).

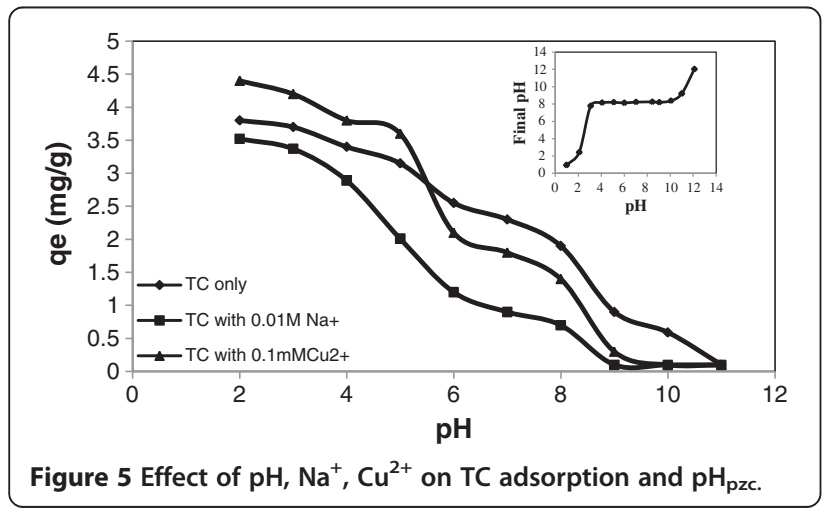

by pumice stone in the presence of $\mathrm{Na}^{+}$and $\mathrm{Cu}^{2+}$ was nearly similar. However, the presence of $\mathrm{Cu}^{2+}$ slightly increased $\mathrm{TC}$ adsorption on pumice stone at low $\mathrm{pH}$ $(\mathrm{pH}<5)$. As a transitional metal cation, $\mathrm{Cu}^{2+}$ could form strong complexes both with $\mathrm{TC}$ and pumice stone $[1,39]$. Therefore, $\mathrm{Cu}^{2+}$ may role as a bridging ion on TC adsorption. The presence of $\mathrm{Cu}^{2+}$ had only minor effects on TC adsorption on pumice stone at high $\mathrm{pH}$

Table 4 Adsorption mechanisms depending on $\mathrm{pH}$ values

\begin{tabular}{ll}
\hline Studied $\mathrm{pH}$ range & Adsorption Mechanisms \\
\hline $2.0<\mathrm{pH}<3.0$ & Cation exchange \\
$3.0<\mathrm{pH}<7.0$ & Cation exchange and surface complexation \\
$\mathrm{pH} 8.0$ & Surface complexation \\
\hline
\end{tabular}




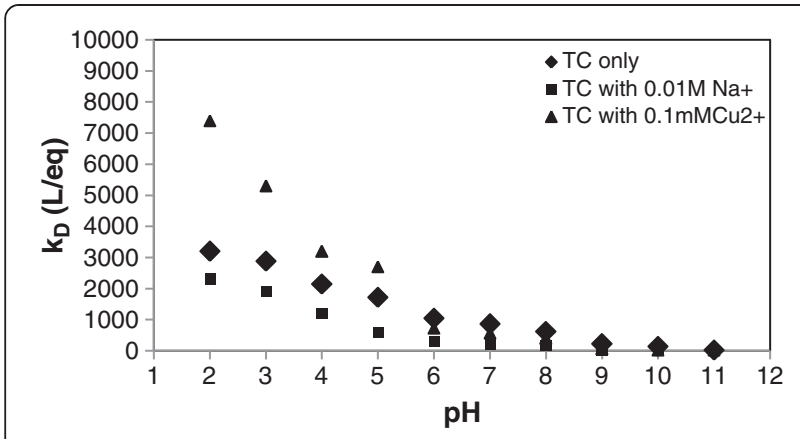

Figure 6 The plot of $\mathrm{K}_{\mathrm{D}}$ against $\mathrm{pH}$.

due to the formation of $\mathrm{CuOH}$ and $\mathrm{Cu}(\mathrm{OH})_{2}$ [1]. Similar observations were reported on the TC adsorption onto soil and sediment in the presence of copper [1]. On the other hand, the presence of $\mathrm{Na}$ cation decreased on TC adsorption. This condition can be explained as the results of an electrostatic competition between TC cations and $\mathrm{Na}^{+}$cations for adsorption to the same binding sites on surface of pumice stone. Similar results were also observed by other researchers $[3,4]$.

In addition, the results were expressed with adsorption partition coefficient $\left(K_{\mathrm{D}}(\mathrm{L} / \mathrm{eq})\right)$ defined in below $[18,19]$ :

$$
K_{D}=\frac{q_{e}}{C_{e} \times C E C}
$$

The plot of $K_{D}$ against pH is presented in Figure 6.

The adsorption partition coefficient is expressed with respect to the CEC because interactions of the TC with specific charge sites on surface of the pumice stone were anticipated [18]. The adsorption partition coefficients $\left(\mathrm{K}_{\mathrm{D}}\right)$ were relatively high at $\mathrm{pH} 2$ and 3 and decreased at $\mathrm{pH} 4-9$ and remained nearly constant between $\mathrm{pH} 9-11$. The results of adsorption capacity (qe) and adsorption partition coefficients $\left(\mathrm{K}_{\mathrm{D}}\right)$ are compatible with each other and $\mathrm{K}_{\mathrm{D}}$ and $\mathrm{q}_{\mathrm{e}}$ values decreased with increasing $\mathrm{pH}$ value. In this case, the $\mathrm{pH}$ value was selected as 3 in further studies.

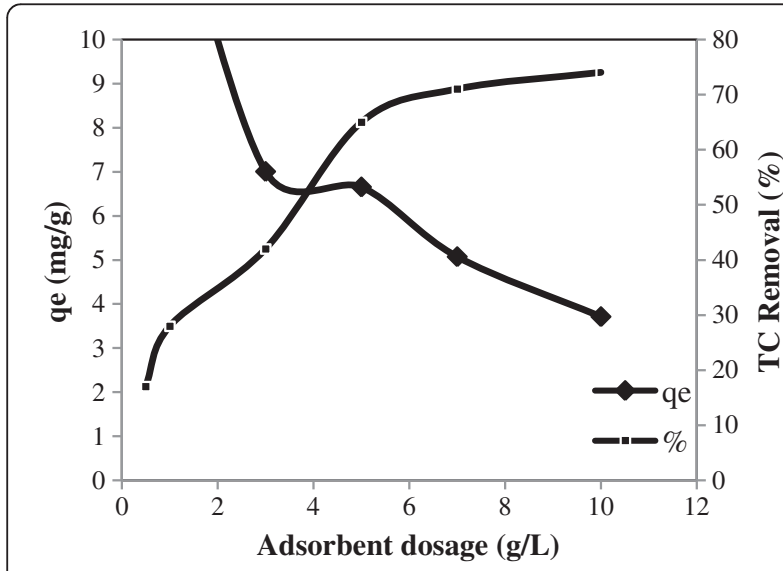

Figure 7 Effect of adsorbent dosage on TC adsorption.

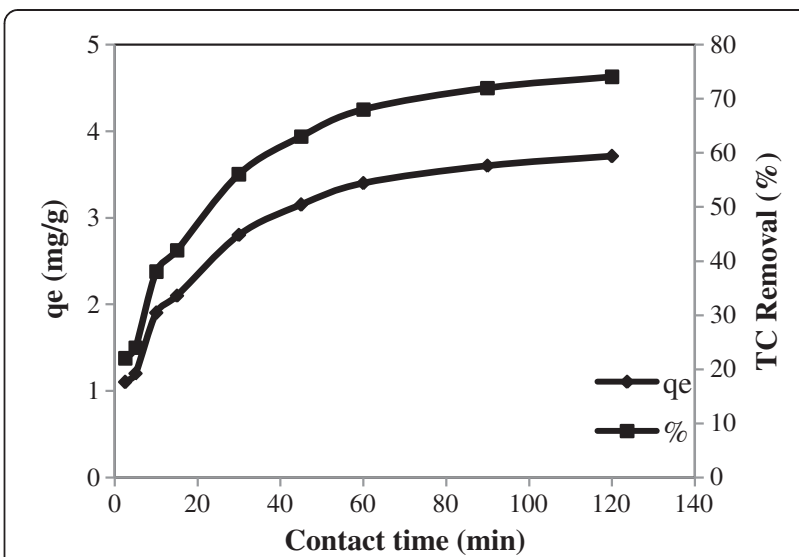

Figure 8 Effect of contact time on TC adsorption.

\section{Effect of adsorbent dosage on adsorption}

The effect of adsorbent dosage on TC adsorption was studied in the range of $0.5-10 \mathrm{~g} / \mathrm{L}$. The TC removal and adsorption capacity at various adsorbent dosages are presented in Figure 7. According to Figure 7, TC percentage removal from $17 \%$ to $74 \%$ increased with increasing the adsorbent dosage from 0.5 to $10 \mathrm{~g} / \mathrm{L}$. The increase of TC adsorption is due to the availability of active binding sites and to the presence of a greater surface area for adsorption [30]. Therefore, the optimum dosage of pumice stone for further experiments of TC adsorption was selected as $10 \mathrm{~g} / \mathrm{L}$.

\section{Kinetics of TC adsorption onto pumice stone}

The effect of contact time in the range of 2.5-120 min and kinetics were calculated. The results regarding TC removal and adsorption capacity are presented in Figure 8.

As shown in this figure, the fifty percent of TC adsorption occurred in the first $30 \mathrm{~min}$ and then the adsorption gradually reached equilibrium after 90 min contact time. The kinetic of TC adsorption on pumice stone was analyzed using the pseudo first-order Lagergren, pseudo

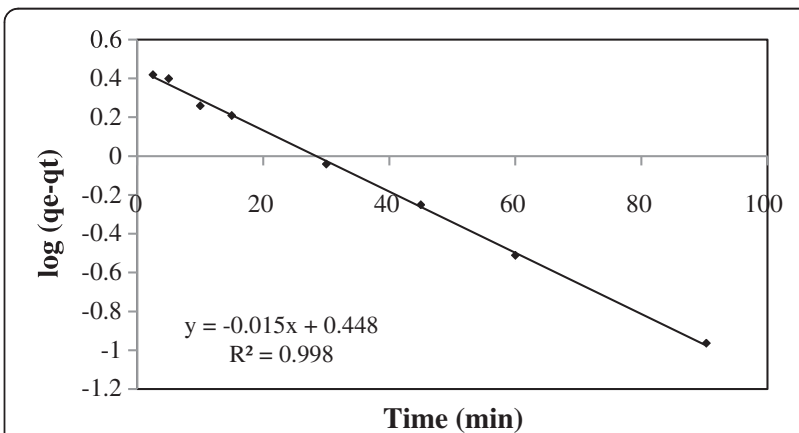

Figure 9 The pseudo first-order kinetic model of TC adsorption on pumice stone. 


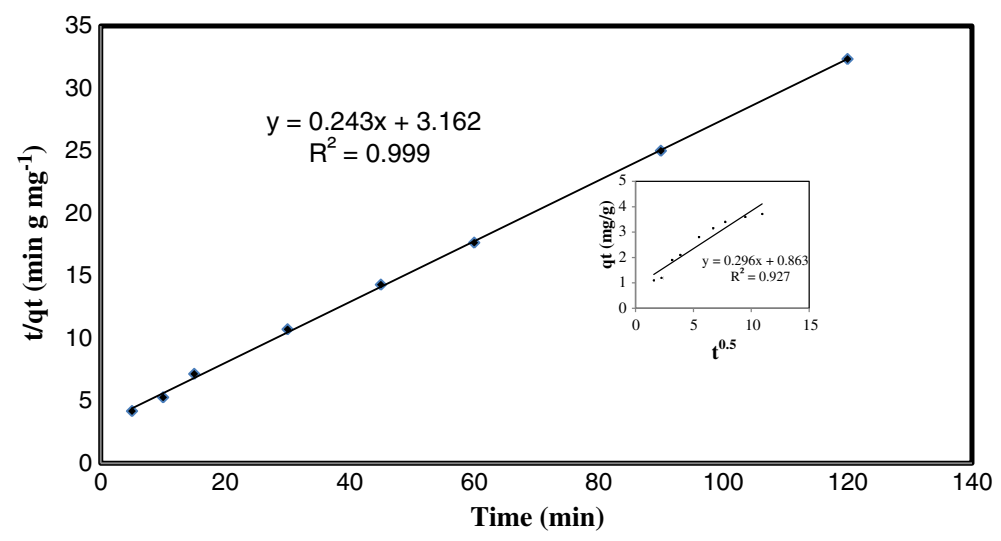

Figure 10 The pseudo second-order kinetic model and the intraparticle diffusion model of TC adsorption on pumice stone.

second-order model and intraparticle diffusion model (Figures 9 and 10).

The pseudo first-order kinetic model of Lagergren is given as [30]:

$$
\log \left(q_{e}-q_{t}\right)=\log q_{e}-\frac{k_{1}}{2.303} t
$$

The pseudo second-order kinetic model is expressed as [30]:

$$
\frac{t}{q_{t}}=\frac{1}{k_{2}\left(q_{e}\right)^{2}}+\frac{t}{q_{e}}
$$

The intraparticle diffusion model equation can be described as [43]:

$$
q_{t}=k_{d} t^{0.5}+C
$$

where $\mathrm{q}_{\mathrm{e}}(\mathrm{mg} / \mathrm{g})$ and $\mathrm{q}_{\mathrm{t}}(\mathrm{mg} / \mathrm{g})$ are the amounts of adsorbed TC on pumice stone at equilibrium and time $\mathrm{t}$ (min), C is the intercept and $k_{1}\left(\mathrm{~min}^{-1}\right), k_{2}$ (g/mg.min) and $k_{d}\left(\mathrm{mg} / g \cdot \min ^{0.5}\right)$ are the rate constant of pseudo first-order kinetic model, pseudo second-order kinetic model and intraparticle diffusion model, respectively. A straight line of $\log \left(q_{e}-q_{t}\right)$ versus $t$ suggest the applicability of pseudo first-order kinetic model. $q_{e}$ and $k_{1}$ can be determined from the intercept and slope of the plot, respectively. The plot $t / q_{t}$ versus $t$ should give a straight line if pseudo second-order kinetics are applicable and $q_{e}$ and $k_{2}$ can be determined from the slope and intercept of the plot, respectively. The intraparticle diffusion model rate constat $\left(\mathrm{k}_{\mathrm{d}}\right)$ and $\mathrm{C}$ can be evaluated from the slope and intercept of the linear plot of $\mathrm{q}_{\mathrm{t}}$ versus $\mathrm{t}^{0.5}$, respectively $[44,45]$. According to this intraparticle diffusion model, the plot of $\mathrm{q}_{\mathrm{t}}$ versus $\mathrm{t}^{0.5}$ should be linear $(\mathrm{C}=0)$ if intraparticle diffusion is involved in the overall adsorption mechanism and the intraparticle diffusion is the sole rate controlling step of the process. If this line did not through the origin $(C \neq 0)$, there are intraparticle diffusion and boundary layer effect in adsorption process. As the intercept value $(C)$ increase, the effect of surface sorption in the rate controlling step increase [46].

The following expression denotes the initial sorption rate $\mathrm{h}(\mathrm{mg} / \mathrm{g} \mathrm{min})$ :

$$
h=k_{2} q_{e}^{2}
$$

The values of correlation coefficients $\left(k_{1}, k_{2}, k_{d}\right)$, equilibrium adsorption capacities $\left(\mathrm{q}_{\mathrm{e}, \mathrm{teo}}\right)$ in these models (pseudo first-order kinetic model, pseudo second-order kinetic model and intraparticle diffusion model) and initial sorption rate $(\mathrm{h})$ are given in Table 5.

According to the fitted linear regression plots, the experimental data are well fitted to the pseudo-second order kinetic model with higher value correlation coefficient $\left(R^{2}>0.999\right)$ compared to pseudo-first order kinetic model. Kinetics of TC adsorption on pumice stone followed the pseudo-second order model, suggesting that the adsorption rate limiting step may be chemisorptions and the adsorption of TC occurs probably via surface complexation reactions at specific adsorption sites [20,30,47]. In addition, present study, the plots indicated that the intraparticle diffusion model was not the sole rate controlling step due to did not pass through the origin $(C \neq 0)$. This indicated that both intra particle diffusion and boundary diffusion affected the TC adsorption on pumice stone.

Table 5 Kinetic parameters of the TC adsorption

\begin{tabular}{lllllllllll}
\hline & \multicolumn{3}{l}{ Pseudo-first order } & \multicolumn{3}{c}{ Pseudo-second order } & \multicolumn{2}{l}{ Intra particle } & h (mg/g.min) \\
\hline $\mathrm{q}_{\mathrm{e}, \text { exp }}$ & $\mathrm{R}^{2}$ & $\mathrm{k}_{1}\left(\mathrm{~min}^{-1}\right)$ & $\mathrm{q}_{\mathrm{e}, \mathrm{cal}}$ & $\mathrm{R}^{2}$ & $\mathrm{k}_{2}(\mathrm{~g} / \mathrm{mg} \cdot \mathrm{min})$ & $\mathrm{q}_{\mathrm{e}, \mathrm{cal}}$ & $\mathrm{R}^{2}$ & $\mathrm{k}_{\mathrm{d}}\left(\mathrm{mg} / \mathrm{g} \cdot \mathrm{min}^{0.5}\right)$ & $\mathrm{C}$ & 0.34 \\
3.71 & 0.998 & 0.03 & 2.80 & 0.999 & 0.02 & 4.11 & 0.927 & 0.30 & 0.87 & \\
\hline
\end{tabular}



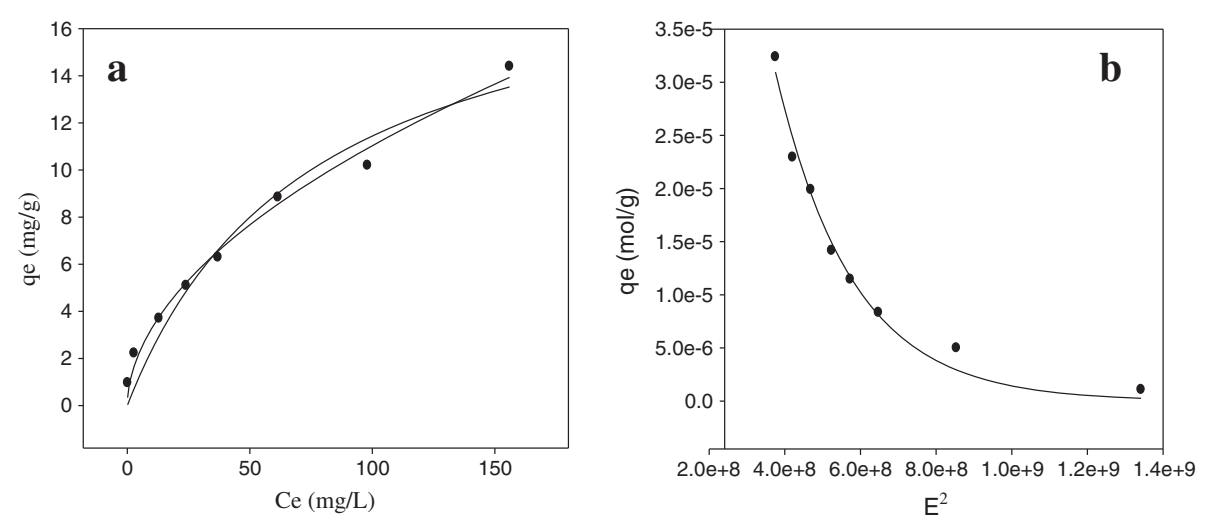

Figure 11 Langmuir, Freundlich (a) and D-R (b) isotherm models.

\section{Adsorption isotherms}

In this study, the Langmuir, Freundlich and D-R adsorption models were used to describe the adsorption equilibrium. All isotherm models parameters were calculated by non-linear regression by using Sigmaplot 11 software. The equation of the Langmuir model is given [48]:

$$
q_{e}=\frac{Q_{m} b C_{e}}{1+b C_{e}}
$$

where, $Q_{m}(\mathrm{mg} / \mathrm{g})$ is the maximum adsorption capacity and $b(\mathrm{~L} / \mathrm{mg})$ is the Langmuir constant related to the affinity between adsorbent and sorbate. The essential feature of the Langmuir isotherm can be expressed in terms of $\mathrm{R}_{\mathrm{L}}$, a dimensionless constant referred to as separation factor or equilibrium parameter. $\mathrm{R}_{\mathrm{L}}$ is calculated using the following equation [49]:

$$
R_{L}=\frac{1}{1+b C_{o}}
$$

The value of $\mathrm{R}_{\mathrm{L}}$ indicates the type of the isotherm to be irreversible $\left(R_{L}=0\right)$, favorable $\left(0<R_{L}>1\right)$, linear $\left(R_{L}=1\right)$ or unfavorable $\left(\mathrm{R}_{\mathrm{L}}>1\right)$.

The Freundlich isotherm is derived to model multilayer adsorption and adsorption on heterogeneous surfaces. The Freundlich isotherm is given by equation [48]:

$$
q_{e}=k_{F} C_{e^{\frac{1}{n}}}
$$

where, $k_{F}(\mathrm{~L} / \mathrm{g})$ is the Freundlich adsorption constant related to the adsorption capacity. $n$ is the adsorption intensity. The $1 / n$ values were between 0 and 1 indicating that the adsorption was favorable at studied conditions.

$\mathrm{D}-\mathrm{R}$ isotherm is more general than the Langmuir isotherm. It was applied to separate the nature of adsorption processes as physical or chemical. The D$\mathrm{R}$ isotherm equation is expressed as follows [50]:

$$
q_{e}=q_{D-R} e^{\beta \varepsilon^{2}}
$$

where $q_{e}(\mathrm{~mol} / \mathrm{g})$ is the amount pollutions adsorbed on the adsorbent at equilibrium, $\mathrm{q}_{\mathrm{D}-\mathrm{R}}(\mathrm{mol} / \mathrm{g})$ is the maximum adsorption capacity, $\beta\left(\mathrm{mol}^{2} / \mathrm{J}^{2}\right)$ is a coefficient related to the mean free energy of adsorption, and $\varepsilon(\mathrm{J} / \mathrm{mol})$ is the Polanyi potential that can be written as:

$$
\varepsilon=R T \ln \left(1+\frac{1}{C_{e}}\right)
$$

The constant $\beta$ gives an idea about the mean free energy $E(\mathrm{~kJ} / \mathrm{mol})$ of adsorption can be calculated using the relationship:

$$
E=\frac{1}{\sqrt{-2 \beta}}
$$

If $E$ value is between 8 and $16 \mathrm{~kJ} / \mathrm{mol}$, the adsorption process follows by chemical ion-exchange and if $E<8 \mathrm{~kJ} /$ mol, the adsorption process is likely physical adsorption.

\begin{tabular}{|c|c|c|c|c|c|c|c|c|c|c|c|c|}
\hline \multirow[b]{2}{*}{$\mathrm{TC}$} & \multicolumn{4}{|l|}{ Langmuir } & \multicolumn{3}{|c|}{ Freundlich } & \multicolumn{5}{|l|}{$\mathrm{D}-\mathrm{R}$} \\
\hline & $\mathrm{Q}_{\mathrm{m}}(\mathrm{mg} / \mathrm{g})$ & $\mathrm{b}(\mathrm{L} / \mathrm{mg})$ & $R_{L}^{*}$ & $R^{2}$ & $\mathrm{k}_{\mathrm{F}}(\mathrm{L} / \mathrm{g})$ & $1 / n$ & $R^{2}$ & $\mathrm{q}_{\mathrm{D}-\mathrm{R}}(\mathrm{mol} / \mathrm{g})$ & $\mathrm{q}_{\mathrm{D}-\mathrm{R}}(\mathrm{mg} / \mathrm{g})$ & $\mathrm{E}(\mathrm{kJ} / \mathrm{mol})$ & $\beta\left(\mathrm{mol}^{2} / \mathrm{J}^{2}\right)$ & $R^{2}$ \\
\hline & 20.02 & 0.0133 & 0.43 & 0.978 & 0.99 & 0.52 & 0.994 & 0.0002 & 90 & 10.08 & $4.92510^{-9}$ & 0.992 \\
\hline
\end{tabular}

Adsorption isotherms for TC on pumice stone are given in Figure 11. The isotherm constants calculated from the Langmuir, Freundlich and D-R isotherm models and the correlation coefficients are given in Table 6.

Table 6 Langmuir, Freundlich and D-R adsorption isotherm parameters of TC

${ }^{*} \mathrm{R}_{\mathrm{L}}$ value calculated in $100 \mathrm{mg} / \mathrm{L}$ initial TC concentration is given. 
Table 7 Maximum adsorption capacity $\left(\mathbf{Q}_{m}\right)$ of various adsorbents for TC

\begin{tabular}{lll}
\hline Adsorbent & $\mathbf{Q}_{\mathbf{m}} \mathbf{( \mathbf { m g } / \mathbf { g } )}$ & Reference \\
\hline Pumice stone & 20.02 & This study \\
Magnetite nanoparticles $\left(\mathrm{Fe}_{3} \mathrm{O}_{4} \mathrm{MnPs}\right)$ & 476 & {$[1]$} \\
Graphene oxide & 212 & {$[3]$} \\
Montmorillonit & 54 & {$[19]$} \\
Activated sludge & 72 & {$[51]$} \\
Kaolinite & 4.32 & {$[25]$} \\
\hline
\end{tabular}

The correlation coefficients of Langmuir ( $R^{2}$ 0.978), Freundlich $\left(R^{2} 0.994\right)$ and $D-R\left(R^{2} 0.992\right)$ models well fitted the adsorption data. The TC adsorption is compatible with both Langmuir and Freundlich isotherms. The applicability of both Langmuir and Freundlich isotherms on the adsorption of TC onto pumice stone shows that adsorption occurs under monolayer and heterogeneous surfaces. From Langmuir model, the maximum adsorption capacity $\left(\mathrm{Q}_{\mathrm{m}}\right)$ was determined to be $20.02 \mathrm{mg} / \mathrm{g}$. Using the Freundlich model, $\mathrm{k}_{\mathrm{F}}$ and $1 / \mathrm{n}$ were found to be 0.99 and 0.52 , respectively. The $1 / \mathrm{n}$ heterogeneity value was between 0 and 1 indicating that the TC adsorption on the pumice stone was favorable at studied conditions.

The $\mathrm{Q}_{\mathrm{m}}$ values of various adsorbents for $\mathrm{TC}$ antibiotics are presented in Table $7[1,3,19,25,51]$.

The calculated $\mathrm{R}_{\mathrm{L}}$ values range between 0 and 1 , indicating that the TC adsorption on pumice stone is favorable.

The mean free energy $(\mathrm{E} ; \mathrm{kJ} / \mathrm{mol}$ ) values calculated from the $\mathrm{D}-\mathrm{R}$ isotherm model were also determined between 8 and $16 \mathrm{~kJ} / \mathrm{mol}$. It was indicating that the adsorption is mainly a chemical process occurs through cation exchange.

\section{Thermodynamic parameters}

In order to explain the mechanism of TC adsorption onto pumice stone, the thermodynamic parameters of adsorption were calculated using free energy change $(\Delta \mathrm{G})$, enthalpy change $(\Delta \mathrm{H})$ and entropy change $(\Delta \mathrm{S})$ given by Equations 11 and 12 [1]:

$$
\Delta G=-R T \ln K_{C}
$$

Table 8 Thermodynamic parameters of TC adsorption on pumice stone

\begin{tabular}{lll}
\hline Parameters & Temperature (K) & Adsorbent \\
\hline$\Delta H(\mathrm{~kJ} / \mathrm{mol})$ & & -4.53 \\
$\Delta S\left(\mathrm{~kJ}(\mathrm{molK})^{-1}\right)$ & & 31.78 \\
$\Delta \mathrm{G}(\mathrm{kJ} / \mathrm{mol})$ & 293 & -13.79 \\
& 303 & -14.23 \\
& 313 & -14.47 \\
& 323 & -14.77 \\
\hline
\end{tabular}

where $\Delta G$ is the Gibbs free energy change, $R$ is the universal gas constant $(8.314 \mathrm{~J} / \mathrm{mol} \mathrm{K}), T$ is the temperature $(\mathrm{K})$ and $K_{C}\left(\mathrm{q}_{\mathrm{e}} / \mathrm{C}_{\mathrm{e}}\right)$ is the equlibrium constant.

The entalpy change $(\Delta \mathrm{H})$ and entropy change $(\Delta \mathrm{S})$ parameters were estimated from the following equation:

$$
\ln K_{C}=\frac{\Delta S}{R}-\frac{\Delta H}{R T}
$$

where the $\Delta H$ and $\Delta S$ in the biosorption process was determined from a slope and intercept of the plot of $\ln K_{C}$ versus $1 / T$, respectively. The values of $\Delta H, \Delta S$ and $\Delta G$ were calculated using equations 11 and 12 (Table 8).

The value of $\Delta H$ and $\Delta G$ were negative, indicating that the TC adsorption process is feasible, spontaneous and exothermic. The positive value of $\Delta S$ shows the increased in randomness at the solid/liquid interface during the adsorption process.

\section{The analysis of ions in aqueous solution after TC adsorption}

The amounts of ions $\left(\mathrm{Ca}^{2+}, \mathrm{Mg}^{2+}, \mathrm{Na}^{+}, \mathrm{K}^{+}\right.$and $\left.\mathrm{Fe}^{3+}\right)$ in aqueous solution after $\mathrm{TC}$ adsorption at optimum conditions ( $\mathrm{pH}$ 3.0, $50 \mathrm{mg} / \mathrm{L} \mathrm{TC}$ concentration, $10 \mathrm{~g} / \mathrm{L}$ pumice stone, $120 \mathrm{~min}$, room temperature) were analyzed and the results were given in Table 9.

According to Table 9, total ion amount in aqueous solution after TC adsorption at optimum conditions is $31.78 \mathrm{mg} / \mathrm{L}$. The amount of adsorbed TC by pumice stone at optimum conditions is $37.09 \mathrm{mg} / \mathrm{g}$. In this case, a major part of $\mathrm{TC}$ adsorption on pumice stone realized with cation exchange between ions $\left(\mathrm{Ca}^{2+}, \mathrm{Mg}^{2+}, \mathrm{Na}^{+}, \mathrm{K}^{+}\right.$ and $\mathrm{Fe}^{3+}$ ) in pumice stone with TC antibiotics.

\section{Conclusions}

In this study, pumice stone was used as a new adsorbent for TC antibiotics removal from the aqueous solution. XRD, FT-IR and SEM data show that TC species adsorbed onto pumice stone. The adsorption mechanism of $\mathrm{TC}$ on pumice stone was cation exchange and surface complexation. The adsorption process is $\mathrm{pH}$ dependent and the optimum $\mathrm{pH}$ was found to be 3 . The adsorption

Table 9 The amounts of ions passing from pumice stone into TC solution

\begin{tabular}{ll}
\hline Parameters & Concentration (mg/L) \\
\hline $\mathrm{Ca}^{2+}$ & 13.2 \\
$\mathrm{Mg}^{2+}$ & 0 \\
$\mathrm{Na}^{+}$ & 3.58 \\
$\mathrm{~K}^{+}$ & 10 \\
$\mathrm{Fe}^{3+}$ & 4.59 \\
Total ion amount & 31.38 \\
\hline
\end{tabular}


isotherm data for pumice stone could be fitted well by both Langmuir and Freundlich isotherm models. The maximum adsorption capacity $\left(\mathrm{Q}_{\mathrm{m}}\right)$ was found to be $20.02 \mathrm{mg} / \mathrm{g}$. TC adsorption reached equilibrium within $90 \mathrm{~min}$ and adsorption kinetics fitted well to the pseudosecond order kinetic model. In the presence of $\mathrm{Na}^{+}$cations, the $\mathrm{TC}$ adsorption decreased with increasing $\mathrm{pH}$. The presence of $\mathrm{Cu}^{2+}$ was facilitated TC adsorption on pumice stone at low $\mathrm{pH}$. Also, the TC adsorption onto pumice stone is found to be feasible, spontaneous and exothermic from thermodynamic studies.

The band changes of amide $\mathrm{I}$ or $\mathrm{C}=\mathrm{O}$ amide groups in FT-IR spectra of TC adsorption on pumice stone was demonstrated that $\mathrm{TC}$ was adsorbed to the pumice stone with cation exchange and surface complexation.

The pumice stone was found to be an efficient adsorbent for the removal of TC antibiotics from aqueous solution. However, the effect of pretreatment for enhances the adsorption capacity of pumice stone can be examined in further studies.

\section{Competing interests}

The authors declare that they have no competing interests.

\section{Authors' contributions}

The overall implementations of this study were the results of efforts by corresponding author. All authors have made contribution into the review and finalization of this manuscript. All authors read and approved the final manuscript.

\section{Acknowledgments}

We would like to thank Rresearch and Application Center of Erciyes University (TAUM), for their help in XRD, FTIR and SEM analysis.

Received: 2 April 2013 Accepted: 21 April 2014

Published: 1 May 2014

\section{References}

1. Zhang D, Niu H, Zhang X, Meng Z, Cai Y: Strong adsorption of chlorotetracyline on magnetite nanoparticles. J Hazard 2011, 192:1088-1093.

2. Kümmerer K: Antibiotics in the aquatic environment-a review Part I. Chemosph 2009, 75:417-434.

3. Gao Y, Zhang YLL, Huang H, Hu J, Shah SM, Su X: Adsorption and removal of tetracycline antibiotics from aqueous solution by graphene oxide. J Colloid Interface Sci 2012, 368:540-546.

4. Gu C, Karthikeyan GK: Interaction of tetracycline with aluminum and iron hydrous oxides. Environ Sci Technol 2005, 39:2660-2667.

5. Ji L, Chen W, Duan L, Zhu D: Mechanisms for strong adsorption of tetracycline to carbon nanotubes: A comparative study using activated carbon and graphite as adsorbents. Environ Sci Technol 2009 43:2322.

6. Ji LL, Chen W, Zheng JBSR, Xu ZY, Zhu DQ, Alvarez PJ: Adsorption of tetracycline on single-walled and multi-walled carbon nanotubes as affected by aqueous solution chemistry. Environ Toxicol Chem 2010, 29:2713.

7. Wang YJ, Jia DA, Sun RJ, Zhu HW, Zhou DM: Adsorption and Cosorption of tetracycline and Copper(II) on Montmorillonite as Affected by Solution pH. Environ Sci Technol 2008, 42:3254.

8. Li R, Yuan Q, Zhang Y, Ling J, Han T: Hydrophilic interaction chromatographic determination of oxytetracycline in the environmental water using silica column. J Liq Chromatogr Relat Technol 2011, 34:511.

9. Gu C, Karthikeyan KG, Samuel D, Sibley J, Pedersen A: Complexation of the antibiotic tetracycline with humic acid. Chemosph 2007, 66:1494-1501.

10. Brown KD, Kulis J, Thomson B, Chapman TH, Mawhinney DB: Occurrence of antibiotics in hospital, residential, and dairy effluent, municipal wastewater, and the Rio Grande in New Mexico. Sci Total Environ 2006, 366:772-783.

11. Karthikeyan KG, Meyer M: Occurrence of antibiotics in wastewater treatment facilities in Wisconsin. USA Sci Total Environ 2006, 361:196-207.

12. Sun HY, Shi X, Mao JD, Zhu DQ: Tetracycline sorption to coal and soil humic acids: An examination of humic structural heterogeneity. Environ Toxicol Chem 2010, 29:1934-1942.

13. Santosa LH, Araújoa AN, Fachinia A, Penab A, Delerue-Matosc C, Montenegro MCBSM: Ecotoxicological aspects related to the presence of pharmaceuticals in the aquatic environment. J Hazard Mater 2010, 175:45-95.

14. Jindal A, Kocherginskaya S, Mehboob A, Robert M, Mackie Rl, Raskin L, Zilles $\mathrm{J}$ : Antimicrobial use and resistance in swine waste treatment systems. Appl Environ Microbiol 2006, 72:7813-7820.

15. Kim SP, Park HK, Chandran K: Propensity of activated sludge to amplify or attenuate tetracycline resistance genes and tetracycline resistant bacteria: a mathematical modeling approach. Chemosph 2010, 78:1071-1077.

16. Jeong J, Song W, Cooper WJ, Jung J, Greaves J: Degradation of tetracycline antibiotics: Mechanisms and kinetic studies for advanced oxidation/ reduction processes. Chemosp 2010, 78:533-540.

17. Chee-Sanford JC, Aminov RI, Krapac IJ, Garrigues-Jeanjean N, Mackie Rl: Occurrence and diversity of tetracycline resistance genes in lagoons and groundwater underlying two swine production facilities. Appl Environ Microbiol 2001, 67:1494-1502

18. Liu N, Wang MX, Liu MM, Liu F, Weng L, Koopal LK, Tan WF: Sorption of tetracycline on organo-montmorillonites. Journal of Hazardous Materi 2012, 225-226:28-35.

19. Figueroa RA, Leonard A, Mackay AA: Modeling tetracycline antibiotic sorption to clays. Environ Sci Technol 2004, 38:476-483.

20. Zhao Y, Geng J, Wang X, Gu X, Gao S: Adsorption of tetracycline onto goethite in the presence of metal cations and humic substances. $J$ Colloid Interface Sci 2011, 361:247-251.

21. Homem V, Santos L: Degradation and removal methods of antibiotics from aqueous matrices e A review. J Environ Mana 2011, 92:304-2347.

22. Pils JRV, Laird DA: Sorption of tetracycline and chlortetracycline on K- and Casaturated soil clays, humic substances, and clay-humic complexes. Environ Sci Technol 2007, 41(6):1928-1933.

23. Wang JT, Hu J, Zhang SW: Studies on the sorption of tetracycline onto clays and marine sediment from seawater. J Colloid Interface Sci 2010, 349(2):578-582.

24. Figueroa RA, Mackay AA: Sorption of oxytetracycline to iron oxides and iron oxide-rich soils. Environ Sci Technol 2005, 39(17):6664-6671.

25. Li Z, Chang PH, Jean JS, Jiang WT, Wang CJ: Interaction between tetracycline and smectite in aqueous solution. J Colloid Interface Sci 2010 341:311.

26. Chang PH, Jean JS, Jiang WT, Li ZH: Mechanism of tetracycline sorption on rectorite. Colloids and Surface A 2009, 339:94.

27. Chang PH, Li ZH, Yu TL, Munkhbayer S, Kuo TH, Hung YC, Jean JS, Lin KH: Sorptive removal of tetracycline from water by palygorskite. J Hazard Mater 2009, 165:148.

28. Caroni ALPF, De Lima CRM, Pereira MR, Fonseca JLC: The kinetics of adsorption of tetracycline on chitosan particles. J Colloid Interface $\mathrm{SCl}$ 2009, 340:182

29. Choi K, Kim SG, Kim SH: Removal of antibiotics by coagulation and granular activated carbon filtration. J Hazard Mater 2008, 151:38.

30. Asgari G, Roshani B, Ghanizadeh G: The investigation of kinetic and isotherm of fluoride adsorption onto functionalize pumice Stone. J Hazard Mater 2012, 17-218:123-132.

31. Akbal F: Adsorption of basic dyes from aqueous solution onto pumice powder. J Colloid Interface Sci 2005, 286:455-458.

32. Kitis M, Kaplan SS, Karakaya E, Yigit NO, Civelekoglu G: Adsorption of natural organic matter from waters by iron coated pumice. Chemosphere 2007, 66:130-138

33. Onar AN, Ozturk B: Adsorption of phosphate onto pumice powder. Environ Technol 1993, 14:1081-1087.

34. Ersoy B, Sariisik A, Dikmen S, Sariisik G: Characterization of acidic pumice and determination of its electrokinetic properties in water. Powder Technol 2010, 197:129-135

35. Arrigo I, Catalfamo P, Cavallari L, Di Pasquale S: Use of zeolitized pumice waste as a water softening agent. J Hazard Mater 2007, 147:513-517.

36. Chuan XY, Mirano M, Inagaki M: Preparation and photocatalytic performance of anatase-mounted natural porous silica, pumice, by 
hydrolysis under hydrothermal conditions. Colloids and Surfaces B: Environmental 2004, 51:255-260.

37. Chang PH, Li Z, Jean JS, Jiang WT, Wang CJ, Lin KH: Adsorption of tetracycline on 2:1 layered non-swelling clay mineral illite. Applied Clay Science 2011, 67-68:158-163.

38. Chang PH, Li Z, Yu TL, Munkhbayer S, Kuo TH, Hung YC, Jean JS, Lin KH: Sorptive removal of tetracycline from water by palygorskite. $J$ Hazard Mater 2009, 165:48-155.

39. Zhao Y, Gu X, Gao S, Geng J, Wang X: Adsorption of tetracycline (TC) onto montmorillonite: Cations and humic acid effects. Geoderma 2012 183-184:12-18.

40. Stephen CK, Muraik SK, Bruningas J, Woodwarl KB: Acidity constants of tetracyline antibiotics. J Am Chem Soc 1956, 78:4155-4158.

41. Qiang Z, Adams C: Potentiometric determination of acid dissociation constants (pKa) for human and veterinary antibiotics. Water Res 2004 38:2874-2890

42. Colaizzi JL, Klink PR: pH-partition behavior of tetracyclines. J of Pharm SCi 1969, 58:1184

43. Dogan M, Alkan M, Türkyilmaz A, Özdemir Y: Kinetics and mechanism of removal of methylene blue by adsorption onto perlite. $J$ Hazard Mater 2004, B109:141-148.

44. Hall KR, Eagleton LC, Acrivos A, Vermeulen T: Pore and solid diffusion kinetics in fixed-bed adsorption under constant pattern conditions. Ind Eng Chem Fundam 1966, 5:212-223.

45. Ho YS, McKay G: Pseudo-second order model for sorption processes. Process Biochem 1999, 34:451-465.

46. Murugesan A, Ravikumar L, Bala VSS, Kumar PS, Vidhyadevi T, Dinesh S, Kirupha S, Kalaivani SS, Krithiga S, Sivanesan S: Removal of $\mathrm{Pb}(\mathrm{II}), \mathrm{Cu}(\mathrm{II})$ and $\mathrm{Cd}(\mathrm{II})$ ions from aqueous solution using polyazomethineamides: Equilibrium and kinetic approach. Desalination 2011, 271:199-208.

47. Behnamfard A, Salarirad MM: Equilibrium and kinetic studies on free cyanide adsorption from aqueous solution by activated carbon. $J$ Hazard Mater 2009, 170:127-133.

48. Sari A, Tuzen M: Kinetic and equilibrium studies of biosorption of $\mathrm{Pb}$ (II) and $\mathrm{Cd}(\mathrm{II})$ from aqueous solution by macrofungus (Amanita rubescens) biomass. J Hazard Mater 2009, 164:1004-1011.

49. Akar T, Kaynak Z, Ulusoy S, Yuvaci D, Ozsari G, Tunali Akar S: Enhanced biosorption of nickel(II) ions by silica-gel-immobilized waste biomass: Biosorption characteristics in batch and dynamic flow mode. J Hazard Mater 2009, 163:1134-1141.

50. Dang VBH, Dogan HD, Dang-Vu T, Lohi A: Equilibrium and kinetics of biosorption of cadmium(II) and copper(II) ions by wheat straw. Bioresour Technol 2009, 100:211-219.

51. Prado N, Ochoa J, Amrane A: Biodegradation and biosorption of tetracycline and tylosin antibiotics in activated sludge bisystem. Process Biochem 2009, 44:1302.

doi:10.1186/2052-336X-12-79

Cite this article as: Guler and Sarioglu: Removal of tetracycline from wastewater using pumice stone: equilibrium, kinetic and

thermodynamic studies. Journal of Environmental Health Science \& Engineering 2014 12:79.

\section{Submit your next manuscript to BioMed Central and take full advantage of:}

- Convenient online submission

- Thorough peer review

- No space constraints or color figure charges

- Immediate publication on acceptance

- Inclusion in PubMed, CAS, Scopus and Google Scholar

- Research which is freely available for redistribution 